\title{
Calli induction in leaf explants of coffee elite genotypes
}

\author{
Indução de calos em explantes foliares de clones elite de café
}

\section{Juliana Costa de Rezende ${ }^{\mathrm{I}}$ Carlos Henrique Siqueira de Carvalho ${ }^{\mathrm{II}}$ Moacir Pasqual ${ }^{\mathrm{III}}$ Ana Carolina Ramia Santos ${ }^{\text {II }}$ Stephan Malfitano de Carvalho ${ }^{\text {IV }}$}

\begin{abstract}
Three experiments were carried out with the objective of achieving high effectiveness in calli induction from high heterozygosis leaf explants of Coffea arabica through indirect somatic embryogenesis. A randomized-block design in a $2 x 5$ factorial arrangement made up of two media [BOXTEL \& BERTHOULY (1996) and TEIXEIRA et al. (2004)] and five $C$. arabica genotypes were used in the first experiment. In the second experiment the embryogenic calli production potential was evaluated in ten genotypes. Each of them was considered as a treatment. In the third experiment the variations in both

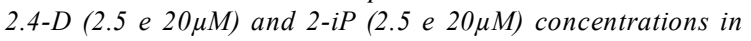
TEIXEIRA et al. (2004) medium and secondary media were evaluated. Crops were kept in a growth room under darkness, at $25 \pm 2^{\circ} \mathrm{C}$. The medium described by TEIXEIRA et al (2004) was found to be superior when compared to that described by BOXTEL \& BERTHOULY (1996) in the 2.2 and 7.2 genotypes. An opposite behavior was noticed in 4.2 genotype, that is, BOXTEL \& BERTHOULY (1996) had medium superiority. Both 3.0 and 5.0 genotypes had the same behavior in both media studied, which shows that the somatic embryo production depends on the genotype. Calli induction depends on the 2-iP and $2.4 \mathrm{D}$ ratio. The $20.0 \mu \mathrm{M}$ of $2.4-\mathrm{D}$ and $20.0 \mu \mathrm{M}$ of $2-i P$ combination caused the highest embryogenic calli induction rate.
\end{abstract}

Key words: Coffea arabica, culture medium, growth regulators.

\section{RESUMO}

Visando a alcançar alta eficiência na indução de calos a partir de explantes foliares de plantas matrizes de $\boldsymbol{C}$. arabica com alta heterozigose, por meio da embriogênese somática indireta, foram instalados três experimentos. $O$ primeiro experimento foi conduzido em esquema fatorial $2 \times 5$, constituído de dois meios de cultura (BOXTEL \& BERTHOULY, 1996 e TEIXEIRA et al., 2004) e cinco genótipos de C. arabica. No segundo experimento, foi avaliado o potencial de produção de calos embriogênicos em 10 genótipos, sendo cada genótipo considerado como um tratamento e, no terceiro experimento, foram avaliadas as variações nas concentrações de 2.4-D (2,5

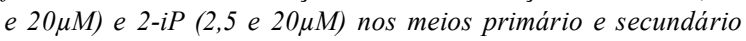
de TEIXEIRA et al. (2004). As culturas foram mantidas a $25^{\circ} \mathrm{C}$, sob obscuridade. Para os genótipos 2.2 e 7.2, verificouse a superioridade do meio de cultura Teixeira et al. (2004) em relação ao meio BOXTEL \& BERTHOULY (1996). No genótipo 4.2 , observou-se o comportamento inverso, ou seja, a superioridade do meio BOXTEL \& BERTHOULY (1996). Os genótipos 3.0 e 5.0 apresentaram o mesmo comportamento em ambos os meios de cultura estudados, evidenciando que a produção de embriões somáticos é fortemente dependente do genótipo. A indução de calos depende da relação de 2-iP e

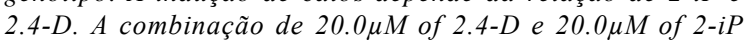
promoveu a maior porcentagem de indução de calos embriogênicos.

Palavras-chave: Coffea arabica, meios de cultura, reguladores de crescimento.

\section{INTRODUCTION}

The introduction of biotechnological methods as a tool for helping genetic breeding programs has been quite useful, mainly in perennial cultures, as

IUnidade Regional do Sul de Minas (Uresm), Empresa de Pesquisa Agropecuária de Minas Gerais (Epamig), 37200-000, Lavras, MG,

Brasil. E-mail: julianacosta @epamig.br. Autor para correspondência.

"Embrapa Café/Fundação Procafé, Varginha, MG, Brasil.

"IIDepartamento de Agricultura (Dag), Universidade Federal de Lavras (Ufla), Lavras, MG, Brasil

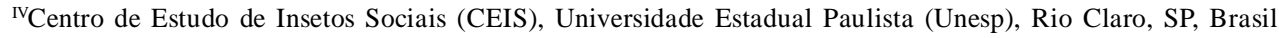


the coffee tree. An important method of in vitro propagation of $\boldsymbol{C}$. arabica plants is the somatic embryogenesis, which consists of embryos development from either haploid or diploid somatic cells, without gamete fusion, which enables the accelerated vegetative propagation and the superior clones genetic uniformity showing a great potential to be explored.

Breeding programs have produced hybrid plants witch superior agronomical features. The Siriema genotype, which was developed by the breeding program carried out by Procafé Foundation, is the result of the cross between $\boldsymbol{C}$. arabica and $\boldsymbol{C}$. racemosa. Such genotype it is not only productive but also resistant to both rust and leaf-miner. Another important population has been development by the Epamig/ UFLA/UFV breeding program. It is the result of cross between 'Icatu' and 'Catuai' cvs. It is resistant to either horizontal or vertical rust, has high plant vigor and productivity.

The advances witch have taken place in the last decades in cloning process by using somatic embryogenesis encourages plans for future exploration of coffee heterozygosis through the development of hybrid varieties. This research was carried out with the objective of seeking high effectiveness for calli induction from leaf explants of elite genotypes developed by the genetic breeding programs in Minas Gerais state.

\section{MATERIAL AND METHODS}

Well grown leaves belonging to the third pair were collected from the plagiotropic branches of the medium third of adult mother plants and then taken to the tissue culture laboratories where the experiments were conducted. An application of Triazol+Estrobilurina fungicides, trade name Sphere $^{\circledR}$ were applied in the mother plants 24 hours before the explants were collected.

The leaves were immersed in a $70 \%$ alcohol solution for one minute and then disinfested by using sodium hypochlorite, at the concentration of $2.4 \%$ (commercial concentration), for 15 minutes. Soon afterwards, the leaves were washed three times with autoclaved distilled water.

After the mediums were prepared, their $\mathrm{pH}$ was adjusted to $5.6 \pm 0.1$ by using $\mathrm{NaOH} 0,1 \mathrm{~N}$ or $\mathrm{HCl}$ $0,1 \mathrm{~N}$, before being autoclaved at $121^{\circ} \mathrm{C}$ and $1 \mathrm{~atm}$, for 20 minutes. With the aid of a scalpel the leaves were cut into approximately $1 \mathrm{~cm}^{2}$ squares and their explants inoculated with the adaxial face of the leaf in contact with the culture medium (TEIXEIRA at al., 2004).

According to the protocol described by TEIXEIRA et al. (2004), the leaf explants were initially inoculated in the primary medium (PM). After 30 days in a growth room, in continuous darkness at $25 \pm 2^{\circ} \mathrm{C}$, they were transferred to the secondary medium (SM), where they remained under the same conditions. A randomized block design was used. Each plot had a Petri dish containing nine explants.

Experiment 1 - Culture mediums and genotypes influence Greenhouse grown $\boldsymbol{C}$. arabica genotypes leaves in $F_{1}$ generation produced by the Coffee plant Genetic Improvement Program conducted by UFLA/ Epamig/UFV and resulting from the cross between Icatu $x$ Catuai cvs were used as explants.

The leaf explants were inoculated in the primarymedium (PM)(TEIXEIRAatal., 2004) or Cmedium (BOXTEL \& BERTHOULY, 1996). After 30 days in growth room under darkness and temperature of $25 \pm 2^{\circ} \mathrm{C}$, they were transferred for the secondary medium, SM (TEIXEIRA at al., 2004) or E medium (BOXTEL \& BERTHOULY, 1996), respectively, in which they stayed for 180 days, under the same previous conditions.

Test tubes measuring $16 \times 160 \mathrm{~mm}$ and containing about $15 \mathrm{~mL}$ of medium were used. It were used six replications (six explants taken as a plot) in a $2 \times 5$ factorial arrangement made up of two media (BOXTEL\& BERTHOULY, 1996 and TEIXEIRA et al., 2004) and five Coffea arabica genotypes was used. Embryogenic calli formation was evaluated after 180 days.

\section{Experiment 2 - Calli formation potential}

Ten genotypes originating from generations $\mathrm{F}_{3}$ progenies resulting from the cross between C.arabica x C.racemosa were studied. They are described as follows: 4-20, 20-5, 10-1, 5-14, 6-38, 14-8, 14-3, 8-10, 02 and 10-8. Each genotype was considered as a treatment. Six Petri dishes were used. Each one corresponded to a replication. Six months after installation the experiment was evaluate through percentage of explants with embryogenic calli.

Experiment 3 - Influence of 2-iP and 2.4-D levels

The treatments consisted of variations in the 2.4-D and 2-iP concentrations in the PM and SM mediums of TEIXEIRA et al. (2004), described as follows: $2.5 \mu \mathrm{M}$ of $2.4-\mathrm{D}$ and $2.5 \mu \mathrm{M}$ of 2 -iP (treatment 1), $2.5 \mu \mathrm{M}$ of 2.4-D and $20.0 \mu \mathrm{M}$ of 2-iP (treatment 2), $20.0 \mu \mathrm{M}$ of 2.4-D and $2.5 \mu \mathrm{M}$ of $2-\mathrm{iP}$ (treatment 3), $20.0 \mu \mathrm{M}$ of 2.4-D and $20.0 \mu \mathrm{M}$ of $2-\mathrm{iP}$ (treatment 4), $20.0 \mu \mathrm{M}$ of 2.4-D and 
9.84 $\mu \mathrm{M}$ of 2-iP in PM medium and $10.0 \mu \mathrm{M}$ of $2.4-\mathrm{D}$ and $9.84 \mu \mathrm{M}$ of 2-iP in SM medium (treatment 5, TEIXEIRA et al. medium (2004), used as control).

It was used 15 replications. Each one corresponded to a replication. Genotype of 03 leaves was used as explants. Five months after, the experiment installation $t$ was evaluated by means of explants rate containing embryogenic calli.

Statistical analyses

In the first experiment, the adjustments were tested for the four models: the first with no factor (null); the second considering the principal culture medium effect; the third incorporating the principal genotype effect and the last, the interaction. In the second experiment, the adjustments were tested for two models: the first with no factor (null) and the second considering the main effect of the genotype, and in the third one, the adjustments were tested for two models: the first with no factor (null) and the second, considering the effect of the five studied treatments.

Deviance Analysis was used in order to select the most appropriate model. Residue analyses noticed that the best adjustments were obtained with the quasibinomial family and the probit connection function. The variance homogeneity was verified and considered satisfactory. The Scott \& Knott averages comparison test was used. Because the percentage data not follow a normal distribution the GLM (Generalized Linear Model, Computational program $\mathrm{R}^{\circledR}$, 2008) routine was used to perform the analyses.

\section{RESULTS}

Experiment 1-Culture mediums influence and genotypes

Different behavior was noticed only for genotypes inoculated in BOXTEL \& BERTHOULY (1996) culture medium. This was showed by the significant effect of the qui-square test at $5 \%$ significance. On the other hand, genotypes inoculated in TEIXEIRA et al. (2004) medium did not show any significance, demonstrating that this culture medium does not influence their behavior.

When inoculated in BOXTEL \& BERTHOULY (1996) medium, the 4.2 genotype formed $19.44 \%$ of embryogenic calli, which is statistically superior to the others treatments (Table 1). In this same culture medium, no embryogenic calli formation was found in 2.2, 5.0 and 7.2 hybrids. The hybrid 5.0 was the only one which did not show any calli formation in TEIXEIRA et al. culture medium (2004).

For 2.2 and 7.2 genotypes TEIXEIRA et al. (2004) culture medium was considered superior when compared to BOXTEL \& BERTHOULY (1996) medium. However 4.2 genotype showed an opposite behavior, which means the superiority of BOXTEL \& BERTHOULY culture medium (1996). The 3.0 and 5.0 showed the same behavior in both culture media studied.

Those two culture media differ especially in relation to 2.4-D, 2-iP and IBA concentrations. In BOXTEL \& BERTHOULY culture medium (1996), 2.4-D the concentration of it doubled from $\mathrm{C}$ medium $(2.26 \mu \mathrm{M})$ to $\mathrm{E}$ medium $(4.52 \mu \mathrm{M})$. Contrarily, in TEIXEIRA's et al. medium (2004), the 2.4-D concentration reduced by half, from medium PM $(20.0 \mu \mathrm{M})$ to medium $\mathrm{SM}(10.0 \mu \mathrm{M})$. In this same protocol, the 2-iP and of IBA concentrations used in PM medium are kept in medium SM. However, those regulators are not used in BOXTEL\& BERTHOULY (1996) secondary medium. Those auxin/cytokinin different ratios used, might have influenced on the embryogenic calli formation of the genotypes studied.

Experiment 2-Calli formation potencial

The qui-square test showed that the genotype influenced the embryogenic calli formation. Significant difference was found among the hybrids studied, with average percentage ranging from 0 (Genotypes 14-8; 14-3 and 8-10) to 53.3\% (genotype 514). There was high variability for the embryogenic

Table 1 - Percentage of embryogenic calli formation in leaf explants of genotypes $2.2 ; 3.0 ; 4.2 ; 5.0$ and 7.2 , developed according to the studied culture mediums.

\begin{tabular}{lccccc}
\hline \multirow{2}{*}{ Culture mediums } & & & & & \\
& G 2.2 & G 3.0 & G 4.2 & G 5.0 & G 7.2 \\
\hline BOXTEL \& BERTHOULY (1996) & $0.0 \mathrm{~b} \mathrm{~B}$ & $6.11 \mathrm{~b} \mathrm{~A}$ & $19.44 \mathrm{a} \mathrm{A}$ & $0.0 \mathrm{~b} \mathrm{~A}$ & $0.0 \mathrm{~b} \mathrm{~B}$ \\
TEIXEIRA et al. (2004) & $2.94 \mathrm{a} \mathrm{A}$ & $6.11 \mathrm{a} \mathrm{A}$ & $5.50 \mathrm{a} \mathrm{B}$ & 0.0 a A & $13.89 \mathrm{a} \mathrm{A}$ \\
\hline
\end{tabular}

${ }^{1}$ Averages followed by the same lower case letter in the horizontal and upper case in the vertical do not differ among themselves, by the Scott $\&$ Knott test, to $5 \%$ of significance. 
calli induction (Figure 1). Genotypes 20-5, 10-1, 5-14 and 6-38 showed more embryogenic calli formation than others. These results corroborate with those obtained in Experiment 1 of this research. Yet they reinforce the hypothesis that the production of somatic embryos is strongly dependent on genotypic factors.

According to the protocol, TEIXEIRA et al. (2004) genotypes which presented an average percentage of embryogenic calli induction above $25 \%$, can be used for the production of clonal seedlings on a commercial scale. On the other hand, there is a need to improve the protocol for calli induction of genotypes $14-8 ; 14-3$ and $8-10$, which did not show any embryogenic calli formation, in order to reach the clonal multiplication process on a commercial scale.

Experiment 3 - 2-iP and 2.4-D levels influence

The qui-square test at $5 \%$ of significance showed significant difference among the studied treatments, by, which showed that the combinations of the studied regulators influenced the embryogenic calli formation. There was high variability for the induction of embryogenic calli in the different 2.4-D and 2-iP concentrations, with percentage average ranging from 2.08 to $38.46 \%$ (Figure 2).

It can be noticed that Treatment $4(20.0 \mu \mathrm{M}$ of 2.4-D and $20.0 \mu \mathrm{M}$ of 2-iP) showed a higher percentage of embryogenic calli, and this reason was statistically superior to Treatment $1(2.5 \mu \mathrm{M}$ of $2.4-\mathrm{D}$ and $2.5 \mu \mathrm{M}$ of 2 -iP), Treatment $2(2.5 \mu \mathrm{M}$ of $2.4-\mathrm{D}$ and $20.0 \mu \mathrm{M}$ of 2 -iP), Treatment $3(20.0 \mu \mathrm{M}$ of $2.4-\mathrm{D}$ and $2.5 \mu \mathrm{M}$ of $2-\mathrm{iP})$ and to Treatment 5 (TEIXEIRA et al., 2004 protocol). In general a good response was obtained in embryogenic calli formation. For instance, in Treatment 4 the calli formation rate was $38.46 \%$.

\section{DISCUSSION}

The variability in the embryogenic calli formation (from 0 to $19.44 \%$, depending on the genotype) corroborates the result found by SANTANA et al. (2004), who claims that one of the main factors related to somatic embryogenesis in coffee concerns to the genotype influence. The somatic embryogenic potential of leaf explants from greenhouse-grown plants of eight $\boldsymbol{C}$. arabica genotypes was investigated by BYESSE et al. (1993) who also found high variability of response for production of somatic embryos among one commercial variety and seven genotypes of $\boldsymbol{C}$. arabica Ethiopian wild type. Leaf explants from 15 trees (genotypes) belonging to the $\mathrm{F}_{3}, \mathrm{~F}_{4}$ and $\mathrm{F}_{5}$ generations of the cross between the $\boldsymbol{C}$. arabica cv. 'Caturra' and the 'Timor Hybrid' were used by MOLINA et al. (2002). Large variations in embryogenic capacity among genotypes were detected with rates ranging from 4.8 to $72.7 \%$.

In their first research, about somatic embryogenesis of $\boldsymbol{C}$. arabica, SÖNDAHL \& SHARP (1977) obtained relatively high rates, reaching $60 \%$ of embryogenic calli. BOXTEL \& BERTHOULY (1996) found that the somatic embryogenesis induction in four genotypes of this species varied from $0 \%$ to $10 \%$.

According to BERTHOULY \& ETIENNE (1999), many Coffea species still have difficulty in regenerating in tissue culture, in spite of the great progress accomplished in the embryogenic cell induction protocols. The accumulation of phenolic compounds such a melanin, suberin, lignin and cutin around the wood plants excised surface changes the cultivation medium, which makes the metabolite intake

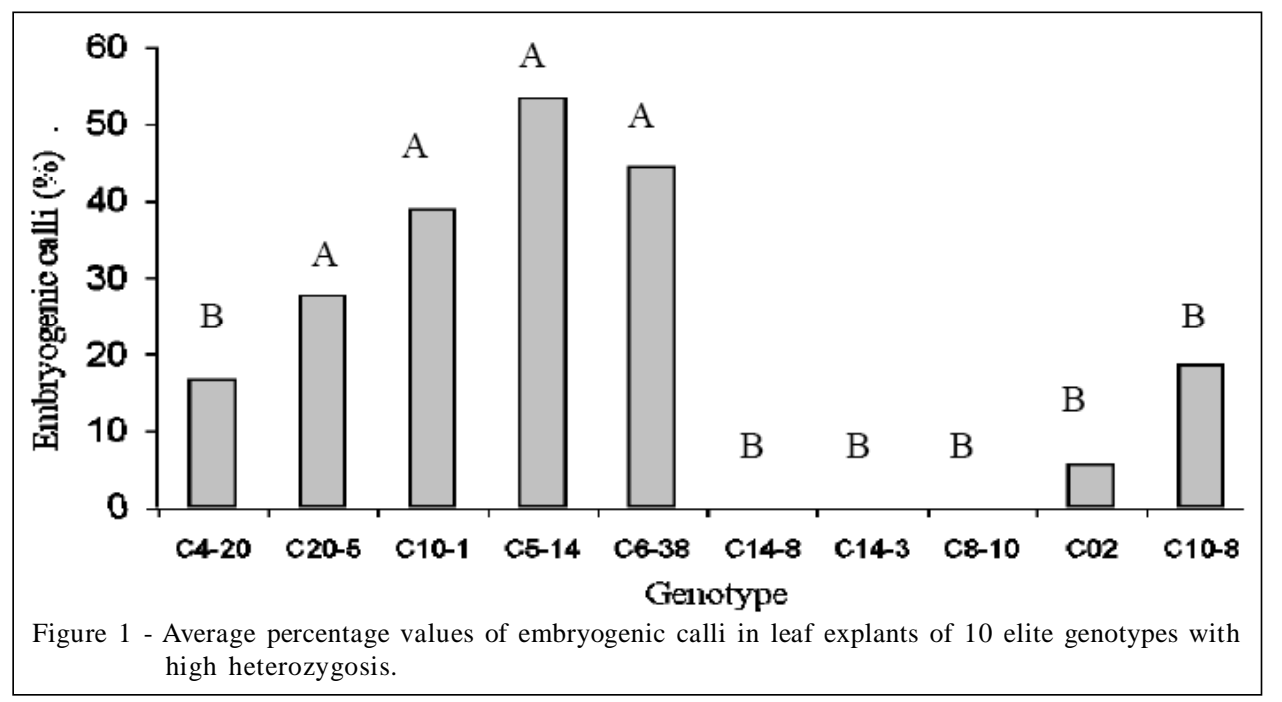

Ciência Rural, v.41, n.3, mar, 2011. 


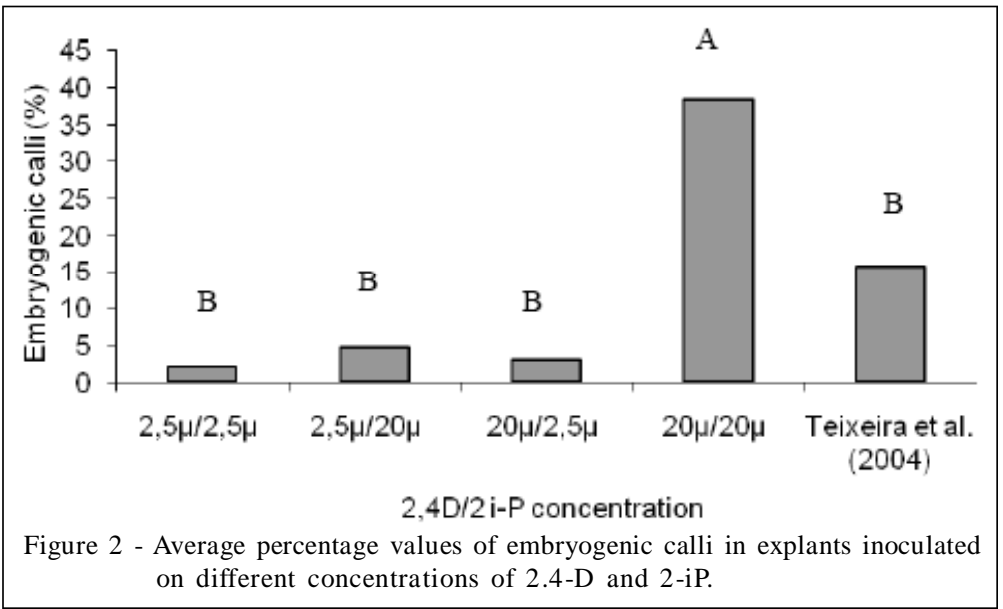

(COSTA et al., 2007). This influence is clearly seen by the variability observed in the embryogenic calli induction frequency of the genotypes studied in the present research.

Although they generally present a better response to the embryogenic calli induction yet differences among $\boldsymbol{C}$. canephora genotypes are frequently noticed (GATICA et al., 2007). According to these authors, the embryogenic calli formation in that species may vary from $0 \%$ to $100 \%$, depending on the genotype, the leaf physiological condition, the collection month and the explants age.

The genotypic potential of embryogenic response is also moderated in other woody plants, such as eucalyptus (BRAVO et al., 2008) and also in herbaceous plants, such as soybean (DROSTE et al., 2010) and maize (FERNANDES et al., 2008).

The significant increase in the embryogenic calli formation was only noticed at the highest concentrations of both growth regulators $(20.0 \mu \mathrm{M})$, showing a synergistic effect when the higher 2-iP and 2.4-D doses were used. In a similar way, MACIEL et al. (2003) and PEREIRA et al. (2007) found that combined action between kinetin and auxin stimulates the somatic embryos induction. On the other hand when HATANAKA et al. (1991) studied the effect of plant growth regulators on somatic embryogenesis in leaf cultures of $\boldsymbol{C}$. canephora, all of the auxins tested (NAA, IBA, IAA and 2.4-D) inhibited the formation of embryos. Yet the maximum number of somatic embryos was obtained on media that contained only cytokinin as a plant growth regulator. 2 -iP in a $5 \mu \mathrm{M}$ concentration was found to be more effective.

Abnormal somatic embryos formation, low regeneration frequency, lack of synchronization in growth, no change of these embryos into plants and no repetition of results were found to limit the development of $\boldsymbol{C}$. arabica effective to somatic embryos protocol. Researches have been development to overcome such constraints. Therefore, with the optimization of the protocols, somatic embryogenesis has a great potential to develop hybrid varieties which generally show higher productivity than the stable cvs. and carry genes which complement then resistance to diseases and insects.

\section{CONCLUSION}

The production of somatic embryos is strongly dependent on the genotype.

The ratio of 2-iP and 2.4-D in both primary and secondary mediums influences calli induction. The $20.0 \mu \mathrm{M}$ of $2.4-\mathrm{D}$ and $20.0 \mu \mathrm{M}$ of $2-\mathrm{iP}$ combination caused the highest embryogenic calli induction rate.

\section{REFERENCES}

BERTHOULY, M.; ETIENNE, H. Somatic embryogenesis of coffee. In: SEMINÁRIO INTERNACIONAL SOBRE BIOTECNOLOGIA DA AGROINDÚSTRIA CAFEEIRA, 3., 1999, Londrina. Anais... Londrina: IAPAR/UFPR/IRD, 1999. p.23-26.

BOXTEL, J. van; BERTHOULY, M. High frequency somatic embryogenesis from coffee leaves. Plant Cell, Tissue and Organ Culture, v.44, p.7-17, 1996. Available from: <http:/ /www.springerlink.com/content/q161407874551883/>. Accessed: Jan 24, 2011. doi: 10.1007/BF00045907.

BYESSE, D. et al. Effect of experimental conditions and genotypic variability on somatic embryogenesis in Coffea arabica. Canadian Journal Botany, v.71, p.1496-1502, 1993. Available from: <http://rparticle.web-p.cisti.nrc.ca/rparticle/ AbstractTemplateServlet?calyLang=eng\&journal $=$ cjb\&volume $=71$ \&year $=1993 \&$ issue $=11 \& \mathrm{msno}=\mathrm{b} 93-181>$. Accessed: Jan 22, 2011. doi: $10.1139 / \mathrm{b} 93-181$ 
BRAVO, C.D.V. et al. Controle genético da regeneração in vitro em progênies de Eucalyptus grandis. Ciência Rural, v.38, p.2181-2185, 2008. Available from: <http:// ww w.s ci e lo.br/s c i e 1 o.ph p ? p id = S 0103 84782008000800014\&script=sci_arttext $>$. Accessed: Jan 20, 2011. doi: $10.1590 / \mathrm{S} 0103-84782008000800014$.

COSTA, A.S. da, et al. Estabelecimento de alecrim-pimenta in vitro. Horticultura Brasileira, v.25, p.68-72, 2007. Available from: <http://www.scielo.br/scielo.php?pid=S010205362007000100013\&script=sci_arttext $>$. Accessed: Jan 23, 2011. doi: 10.1590/S0102-05362007000100013.

DROSTE, A. et al. Screening of Brazilian soybean genotypes with high potential for somatic embryogenesis and plant regeneration. Pesquisa Agropecuária Brasileira., v.45, p.715-720, 2010. Available from: <http://www.springerlink.com/ content/rh4132633802xq43/>. Accessed: Jan 21, 2011. doi: 10.1023/A: 1013874221569 .

FERNANDES, E.H. et al. Embriogênese somática a partir de embriões imaturos em genótipos de milho. Ciencia Rural, v.38, n.9, p.2604-2607, 2008. Available from: <http:// www.scielo.br/scielo.php? script $=$ sci_arttext\&pid $=$ S0103 84782008000900031>. Accessed: Jan 21, 2011. doi: 10.1590/ S0103-84782008000900031.

GATICA, A.M. et al. Comparison of three in vitro protocols for direct somatic embryogenesis and plant regeneration of Coffea arabica L. cvs. Caturra e Catuaí. Agronomia Costarricense, v.31, p.85-94, 2007. Available from: <http:/ /redalyc.uaemex.mx/pdf/436/43631110.pdf〉. Accessed: Jan 22, 2011 .

HATANAKA, T. et al. Effect of plant growth regulators on somatic embryogenesis in leaf cultures of Coffea canephora. Plant Cell Reports, v.10, p.179-182, 1991. Available from: <http://www.springerlink.com/content/r82078521wn5m173/>. Accessed: Jan 24, 2011. doi: 10.1007/BF00234290.

MACIEL, A.L. de R. et al. Embriogênese somática indireta em explantes foliares de Coffea arabica L. cv. Obatã. Ciência e Agrotecnologia, v.27, n.1, p.107-116, 2003. Available from: <http://www.editora.ufla.br/site/_adm/upload/revista/27-12003_13.pdf $>$. Accessed: Jan 23, 2011.

MOLINA D. et al. The effect of genotype and explant age on somatic embryogenesis of coffee. Plant Cell, Tissue and Organ Culture, v.71, p.117-123, 2002. Available from: <http://www.springerlink.com/content/k11266842815g30v/>. Accessed: Jan 21, 2011. doi: 10.1023/A:1019965621041.

PEREIRA, A.R. et al. Embriogênese somática direta em explantes foliares de Coffea arabica L. cv. 'Acaiá Cerrado': efeito de cinetina e ácido giberélico. Ciência e agrotecnologia, v.31, p.332-336, 2007. Available from: <http://www.scielo.br/scielo.php?pid=S1413$70542007000200010 \&$ script $=$ sci_arttext $\&$ thng=en $>$. Accessed: Jan 21, 2011. doi: 10.1590/S1413-70542007000200010.

PIERSON, E.S. et al. In vitro development of embryoids from punched leaf discs of Coffea canephora. Protoplasma, v.115, p.208-216, 1983. Available from: <http://www.springerlink.com/ content/lh072173h1674v38/>. Accessed: Jan 22, 2011. doi: 10.1007/BF01279811.

R DEVELOPMENT CORE TEAM. $R$ : a language and environment for statistical computing. Vienna, Austria: $R$ Foundation for Statistical Computing, 2008. Available from: <http://www.R-project.org>. On line. Accessed: Apr 21, 2010.

SÖNDAHL, M.R.; SHARP, W.R. High frequency induction of somatic embryos in culture leaf explant of Coffea arabica. Zeitschrift fuer Pflanzen Physiogie, v.81, p.395-408, 1977.

SANTANA, N. et al. Somatic embryogenesis: a valuable alternative for propagating selected robusta coffee (Coffea canephora) clones. In vitro Cellular and Developmental Biology - Plant, v.40, p.95-101, 2004. Available from: <http:/ /www.springerlink.com/content/31r48463 x11 u 8718/>. Accessed: Jan 21, 2011. doi: 10.1023/A:1013874221569.

TEIXEIRA, J.B. et al. Multiplicação clonal de café (Coffea arabica $\mathrm{L}$ ) via embryogenesis somática. Brasília: Embrapa Recursos Genéticos e Biotecnologia, 2004. 39p. (Documentos). Available from: <http://www.cenargen.embrapa.br/publica/ trabalhos/doc121.pdf>. Accessed: Jan 21, 2011. 